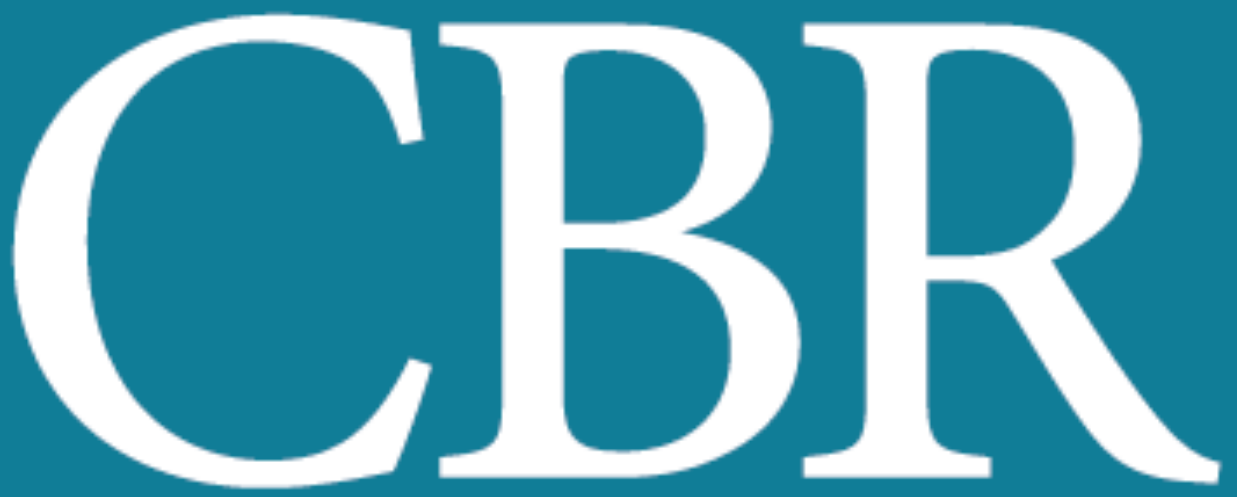

\title{
INTERNATIONAL JOURNAL OF CANCER AND BIOMEDICAL RESEARCH
}

https://jcbr.journals.ekb.eg

Editor-in-chief

Prof. Mohamed Labib Salem, PhD

Paclitaxel as a possible continuation maintenance therapy in advanced non-small cell lung cancer

S.F. Gohar, A.H. Hegazy, S.A. Alhassanin, M.A. Shehata, N.M. Abd El Bary, K.K. Abd El Aziz 


\section{International Journal of Cancer \& Biomedical Research \\ (IJCBR) https://jcbr.journals.ekb.eg}

IJCBR is an Int. journal published by the Egyptian Society of Cancer Research (EACR, established in 2014, http://eacr.tanta.edu.eg) and sponsored by the Egyptian Knowledge Bank (EKB: www.ekb.eg).

IJCBR has been approved by the Supreme Council of Universities, Egypt with score 7 (http://egjournal.scu.eg). The journl is cited by google scholar and registered by Publons (https://publons.com). The journal has recently been evaluated in 2020 by Nature Springer with a good standing.

\section{Scope of IJCBR}

- Drug discovery from natural and synthetic resources

- BioMedical applications of nanotehnology

- Sem cell biology and its application

- Basic and applied biotechnology

- Inflammation and autoimmune diseases

- In slico models and bioinformatics

- In vitro and In vivo preclinical animal models

- Cellular and molecular cancer biology

- Cancer Immunology and Immunotherapy

- New methods for prediction, early detection, diagnosis prognosis and treatment of dieases.

- Immunology in health and dieases

- Anti-microbial defense mechanisms

- Cellular and molecular physhiology and pahthology of diseases

\section{IJCBR Editor,}

Prof. Mohamed Labib Salem, PhD

Professor of Immunology

Faculty of Science, Tanta Universiy, Egypt 


\title{
Paclitaxel as a possible continuation maintenance therapy in advanced non-small cell lung cancer
}

\author{
S.F. Gohar, A.H. Hegazy, S.A. Alhassanin, M.A. Shehata, N.M. Abd El Bary, K.K. Abd El Aziz \\ Clinical Oncology Department, Faculty of Medicine, Menoufia University, Egypt
}

\section{IIII}

ABSTRACT

1⿴ ARTICLE INFO

Background: Understanding of the molecular basis of lung cancer have led to the development of targeted agents with a significant clinical benefit. This benefit is confined to patients with specific molecular tumor characteristics. However, chemotherapy represents backbone of treatment in fit patients and is associated with a significant overall survival prolongation and quality of life improvement. Aim: to evaluate the effect a continuation maintenance therapy with paclitaxel in advanced NSCLC patients with weekly paclitaxel. Patients and Methods: The current study included patients with advanced non-small cell lung cancer (NSCLC) (stage IIIB or IV) with performance status $\leq 2$ who experienced good initial good response, or stable disease after receiving 4 cycles of paclitaxel carboplatin. Patients were randomized into 2 arms, the first arm received weekly paclitaxel $\left(70 \mathrm{mg} / \mathrm{m}^{2}\right)$ as continuation maintenance therapy for 3 weeks of 4 weeks cycle. The treatment was continued till disease progression or unacceptable toxicity (maintenance arm). The second arm was kept under observation (observation arm). Results: There were better lung cancer symptoms scale in maintenance arm. Both time to progression and overall survival for the maintenance arm was higher $(P$ value 0.16 and 0.047 , respectively). Treatment related toxicities were significantly higher in the maintenance arm as compared to the observation arm $(P$ value $<0.001)$. Conclusion: Maintenance with paclitaxel can be a reasonable option in patients with NSCLC who experienced complete or partial response after initial paclitaxel carboplatin combination.

Keywords: Continuation maintenance, Chemotherapy, Ling cancer, NSCLC, Paclitaxel, Survival

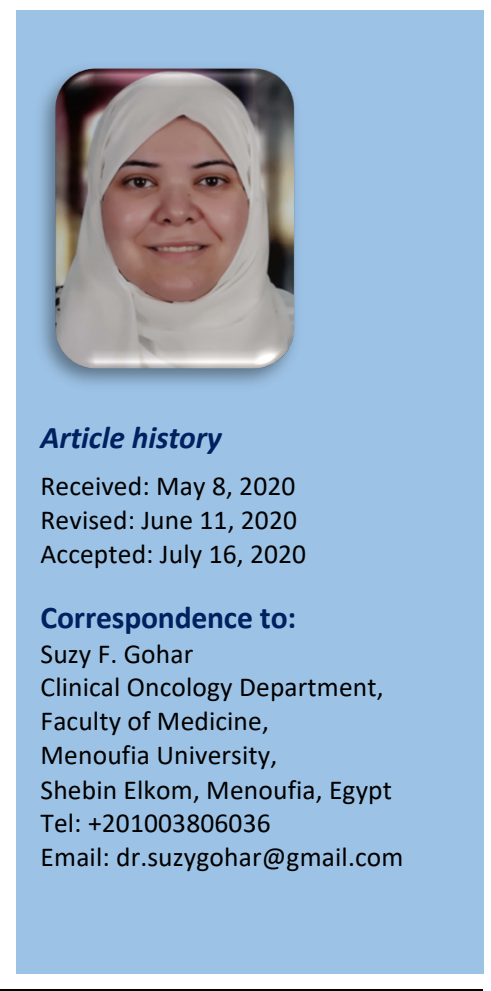

Editor-in-Chief: Prof. M.L. Salem, PhD - Article DOI: 10.21608/JCBR.2020.29694.1036

\section{INTRODUCTION}

Lung cancer remains the most common malignant tumor after non-melanoma skin cancer, where lung cancer deaths exceed those from any other malignancy worldwide (Planchard etal.,2019). Advanced or metastatic non-small-cell lung cancer (NSCLC) has poor prognosis, and 1-year survival rates are $30 \%$ to 40\% (Barlesi et al.,2016).Chemotherapy with platinum doublets is one of the options for treatment of advanced NSCLC (Planchard etal.,2019). Studies could not find overall survival (OS) benefit of six versus fewer cycles of first-line platinum-based doublets. However, a longer progression free survival (PFS) coupled with significantly higher toxicity was reported in patients receiving six cycles (Rossi et al., 2014).
Maintenance therapy is one strategy that has been investigated extensively in recent years as a way of improving outcomes in patients with NSCLC (Coate et al., 2009). Although several active chemotherapeutic and targeted agents are now available for the treatment of advanced NSCLC, not all of them are suitable for administration for prolonged number of cycles (Custodio et al., 2012). The optimal maintenance treatment (MT) agent should be associated with proven efficacy, a favorable toxicity profile and the ability to prolonged administration without significant risk of cumulative toxicity (Custodio et al., 2012). Continuation maintenance' therapy is the maintained use of an agent included in first-line treatment after four cycles of platinum-based chemotherapy (Planchard etal., 2019). 
The toxicity from platinum-based doublet chemotherapy is derived mainly from the platinum component, and that most patients cannot tolerate prolonged administration of platinum-based doublets (Coate et al., 2009). Platinum-based doublets for four cycles followed by less toxic maintenance monotherapy, or four cycles are recommended in patients who are not suitable for maintenance monotherapy up to a maximum of six (Planchard etal., 2019).

As carboplatin paclitaxel combination is generally considered as an effective regimen with acceptable toxicity profile the current study was conducted to evaluate the effect of weekly paclitaxel as continuation maintenance therapy in advanced NSCLC patients.

\section{PATIENTS AND METHODS}

Inclusion criteria: This study included patients who were diagnosed with advanced non-small cell lung cancer (NSCLC) with stage IIIB (T4 N2 or any $\mathrm{T}$ N3 disease) and stage IV disease ( $\mathrm{T}$ any $\mathrm{N}$ M1) with performance status (PS) $\leq 2$.The patients accepted to participate in the study and presented to Clinical Oncology Department, Menoufia University Hospitals from 1-5-2015 till 30-4-2017.

Exclusion criteria: Patients with P.S $>2$ or Comorbidities like diabetic neuropathy, advanced cardiac disease, renal and/ or liver failure and patients presented with brain metastases were excluded.

Protocol outline: After written consent, all patients were initially subjected to: thorough history (age, occupation, special habits, family history of malignancy and comorbidities), clinical examination and investigation in the form of: complete blood picture (CBC), chemistry profile, CT chest, abdomen, and pelvis with contrast, bone scan and magnetic resonance image (MRI) of the brain with contrast. Tumor characteristics including histological subtype, grade, stage, and type of distant metastasis was identified. Treatment and monitoring of the patients.

All patients received carboplatin (AUC 5) paclitaxel $\left(175 \mathrm{mg} / \mathrm{m}^{2}\right)$ as first line for 4 cycles and evaluated every 2 cycles. During the initial chemotherapy period patients were followed up by clinical examination, routine laboratory investigations done before every cycle of chemotherapy. CT chest, abdomen, and pelvis with contrast after 2,4 cycles of first line chemotherapy were done. Bone scan was done every 6 months for patients with bone metastasis. Bone scan was done if there are symptoms, or on disease progression for patients with no bone metastasis. Response to treatment was assessed according to revised RECIST (response evaluation criteria in solid tumors) guideline (version 1.1) (Eisenhauer et al., 2009).

Patients who developed disease progression after 2 or 4 cycles of first line chemotherapy and patients who developed grade II-III neuropathy after first line chemotherapy were excluded as completion of treatment will be a problematic. Then, the patients with initial good response, or stable disease were randomized by 2 cohort groups into 2 arms. The maintenance arm (included 46 patients), in which the patients received weekly paclitaxel $(70 \mathrm{mg} / \mathrm{m} 2)$ as continuation maintenance therapy for 3 weeks of 4 weeks cycle. These patients were evaluated every 12 weeks, continued till disease progression or unacceptable toxicity. The observation arm included 46 patients who were was kept under follow up with no further treatment.

Patients who progressed on maintenance therapy in maintenance arm or during follow up in no treatment arm who were fit, received second line chemotherapy (gemcitabine, vinorelbine or etoposide chemotherapy). In cases with bone metastases monthly bisphosphonates were considered. Patients with painful bony disease or brain metastases, uncontrolled hemoptysis or chest pain received palliative radiotherapy. Follow up was completed till 31-5-2018 and the median follow up period was 14 months.

Toxicity was assessed every cycle of chemotherapy using CTCAE (common toxicity criteria of adverse events) version 4 . The quality of life was assessed using European Organization for Research and Treatment of Cancer (EORTC) Quality of Life Questionnaire (QLQ-C30), and special QLQ.LC13) after 4 cycles 
of first line chemotherapy and after 12 weeks of maintenance therapy. The questionnaires were administered at the clinic.

Statistical analysis: The items on 2 measures were scaled and scored using the recommended EORTC procedures. Algorithm 1: QLQ C30 Questions: Of 30 items (1-30). Raw scores for each item range from 1-4 which require reverse scoring and calibration. Raw score is computed by summing across the thirty items. Raw score (thus), ranges between (30-120). The latter is transformed to $(0-100 \%)$. $100 \%$ representing best QOL \& 0 representing the lowest QOL. Scoring was measured by considering (Actual raw scale score -lowest possible raw score (30)/ possible raw score range (120-30)) * 100. Algorithm 2: LC13 Questions: Of 13 items (1-13). Raw scores for each item range from 1-4 which require reverse scoring and calibration. Raw score is computed by summing across the thirteen items. Raw score (thus), ranges between (13-52). Latter is transformed to (0100\%). 100\% representing the best QOL \& 0 representing the lowest $\mathrm{QOL}$, Scoring was measured by considering (Actual raw scale score -lowest possible raw score (13)/ possible raw score range (52-13))*100. Progression-free survival (PFS) was calculated from the date of diagnosis to date of progression. The results were collected, tabulated and statistically analyzed by an IBM compatible personal computer with SPSS statistical package version 23 (SPSS Inc. Released 2015. IBM SPSS statistics version 23, Armnok, NY: IBM Corp.

\section{RESULTS}

A total number of 118 patients were recruited, 3 patients died without completion of the first line chemotherapy, 13 patients were excluded due to disease progression after 2-4 cycles of the first line chemotherapy, 10 patients were excluded due to grade II or III neuropathy at the time of randomization. The 92 patients were randomized as: 46 patients in maintenance arm and 46 patients in observation arm.

Most of the patients were males $165.2 \%$ in maintenance arm, $67.4 \%$ in observation arm). The most common histological subtype was adenocarcinoma $(82.6 \%$ in arm 1 , and $78.3 \%$ in arm 2) and the most common stage was stage
IV (60.9\% in arm 1 , and $69.6 \%$ in arm 2). The most common histological subtype was adenocarcinoma $(82.6 \%$ in arm 1 , and $78.3 \%$ in arm 2) and the most common stage was stage IV (60.9\% in arm 1, and $69.6 \%$ in arm 2). There was no significant difference between any of studied variables in both arms (Table 1). Response analysis for both arms show no significant difference between response at the time of randomization ( $P$ value 0.99 ). After 3 months of randomization, however, there was significant difference between both arms, $P$ value $(0.013)$ regarding response in favor for maintenance arm (Table 2).

Among the maintenance arm, 28 patients discontinued paclitaxel maintenance therapy due to disease progression, 4 patients discontinued due to grade 3 neuropathy and 14 patients (30.4\%) continued maintenance paclitaxel till the end of study. Most patients who completed paclitaxel maintenance therapy till the end of follow up period was 0 PS (85.7\%), stage IIIB (57.1\%), grade II (42.9\%), and all of them were adenocarcinoma. Most patients who stopped treatment $(53.1 \%)$ were 1 PS, stage IV $(68.8 \%)$, grade 3 , undifferentiated, and some of them were squamous, large cell, and undifferentiated histology (Table 3). The median duration of paclitaxel therapy was 18 weeks. There was highly statistically significant association between duration of paclitaxel therapy and PFS (P value <0.001) (Table 4).

Among the maintenance arm, there was a significant association between the patients' initial response to chemotherapy and OS ( $P$ value 0.021 ). On the other hand, the patients' response after 3 months of the maintenance therapy were significantly affected both PFS and OS ( $P$ value 0.002 versus 0.018 ) (Table 5 ). Treatment related toxicities namely anemia, diarrhea and peripheral neuropathy were significantly higher ( $P$ value $0.017,0.001$ and $<0.001$, respectively) in the maintenance arm as compared to the observation arm (Table 6). In Table 7, there was no significant difference between the global health status, functional, symptom scales at the time of randomization and after 3 months of maintenance therapy in both arms. 
Table 1. Patients and disease characteristics at the time of presentation.

\begin{tabular}{|c|c|c|c|c|}
\hline Character & $\begin{array}{l}\text { Arm (1) } \\
(n=46) \\
\text { No. (\%) }\end{array}$ & $\begin{array}{l}\text { Arm (2) } \\
(n=46) \\
\text { No. (\%) }\end{array}$ & $x^{2}$ & $P$ value \\
\hline $\begin{array}{l}\text { Age (yrs) } \\
\text { mean } \pm S D\end{array}$ & $54.86 \pm 8.42$ & $57.71 \pm 8.21$ & 1.64 & 0.10 \\
\hline Gender & & & & \\
\hline $\begin{array}{l}\text { Male } \\
\text { Female }\end{array}$ & $\begin{array}{l}30(65.2) \\
16(34.8)\end{array}$ & $\begin{array}{l}31(67.4) \\
15(32.6)\end{array}$ & 0.04 & 0.82 \\
\hline Smoking & & & & \\
\hline $\begin{array}{l}\text { Yes } \\
\text { No } \\
\text { Ex-smoker }\end{array}$ & $\begin{array}{l}22(47.8) \\
22(47.8) \\
2(4.3)\end{array}$ & $\begin{array}{l}22(47.8) \\
24(52.2) \\
0(0.0)\end{array}$ & 1.73 & 0.64 \\
\hline $\begin{array}{l}\text { Performance } \\
\text { status (PS) }\end{array}$ & & & & \\
\hline $\begin{array}{l}0 \\
1 \\
2\end{array}$ & $\begin{array}{l}24(52.2) \\
19(41.3) \\
3(6.5)\end{array}$ & $\begin{array}{l}17(37.0) \\
23(50.0) \\
6(13.0)\end{array}$ & 2.52 & 0.31 \\
\hline Grade & & & & \\
\hline $\begin{array}{l}\text { I, II } \\
\text { III, undifferentiated }\end{array}$ & $\begin{array}{l}24(52.2) \\
22(47.8)\end{array}$ & $\begin{array}{l}22(47.8) \\
24(52.2)\end{array}$ & 0.17 & 0.67 \\
\hline $\begin{array}{l}\text { Histology } \\
\text { Adenocarcinoma } \\
\text { Others }\end{array}$ & $\begin{array}{l}38(82.6) \\
8(! 7.4)\end{array}$ & $\begin{array}{l}36(78.3) \\
10(21.7)\end{array}$ & 0.27 & 0.599 \\
\hline $\begin{array}{l}\text { Stage } \\
\text { IIIB } \\
\text { IV }\end{array}$ & $\begin{array}{l}18(39.1) \\
28(60.9)\end{array}$ & $\begin{array}{l}14(30.4) \\
32(69.6)\end{array}$ & 0.76 & 0.38 \\
\hline
\end{tabular}

Table 2. Response analysis in both arms at time of randomization and after 3 months of randomization.

\begin{tabular}{|c|c|c|c|c|}
\hline Response & $\begin{array}{l}\text { Arm } 1 \\
(n=46) \\
\text { No. }(\%)\end{array}$ & $\begin{array}{l}\text { Arm } 2 \\
(n=46) \\
\text { No. (\%) }\end{array}$ & $x^{2}$ & P value \\
\hline \multicolumn{5}{|c|}{ Responders versus non-responders at time of randomization } \\
\hline Responders (CR, PR) & $14(30.4)$ & 14(30.4) & 0.99 & 0.99 \\
\hline Stable disease (SD) & $32(69.6)$ & $32(69.6)$ & & \\
\hline \multicolumn{5}{|c|}{ Responders versus non- responders after 3 months of randomization } \\
\hline Responders (CR, PR) & $10(21.7)$ & $2(4.3)$ & 6.13 & 0.013 \\
\hline Non responders (SD, PD) & $36(78.3)$ & $44(95.7)$ & & \\
\hline
\end{tabular}

CR: complete response, PR: partial response, PD: progressive disease, SD: stable disease.

Table 3. Characters of patients who completed maintenance therapy among maintenance arm.

\begin{tabular}{|c|c|c|c|c|}
\hline Character & $\begin{array}{l}\begin{array}{l}\text { Completed } \\
(n=14)\end{array} \\
\text { No. }(\%)\end{array}$ & $\begin{array}{l}\text { Stopped } \\
(n=32) \\
\text { No. (\%) }\end{array}$ & Test of sig & P value \\
\hline $\begin{array}{l}\text { Age (years) } \\
\text { mean } \pm S D\end{array}$ & $54.86 \pm 4.27$ & $54.87 \pm 9.76$ & $t=0.007$ & 0.995 \\
\hline \multicolumn{5}{|l|}{ Stage } \\
\hline IIIB & $8(57.1)$ & $10(31.3)$ & $\chi^{2}=2.74$ & 0.098 \\
\hline IV & $6(42.9)$ & $22(68.8)$ & & \\
\hline \multicolumn{5}{|l|}{ Performance } \\
\hline 0 & $12(85.7)$ & $12(37.5)$ & One-way & \\
\hline 1 & $2(14.3)$ & $17(53.1)$ & ANOVA $=8.34$ & 0.007 \\
\hline 2 & $0(0.0)$ & $3(9.4)$ & & \\
\hline \multicolumn{5}{|l|}{ Grade } \\
\hline I, II & $10(71.4)$ & $14(43.8)$ & $\mathrm{FE}=2.99$ & 0.084 \\
\hline III, undifferentiated & $4(28.6)$ & $18(56.3)$ & & \\
\hline \multicolumn{5}{|l|}{ Histology } \\
\hline Adenocarcinoma & $14(100.0)$ & $24(75.0)$ & $\mathrm{FE}=4.23$ & 0.040 \\
\hline Others & $0(0.0)$ & $8(25.0)$ & & \\
\hline
\end{tabular}


Table 4. Association of duration of maintenance therapy with OS, PFS.

\begin{tabular}{ccc}
\hline Character & \multicolumn{2}{c}{ Duration of paclitaxel } \\
& $\mathbf{R}$ & P value \\
\hline OS & 0.190 & 0.207 \\
\hline PFS & 0.836 & $<0.001$ \\
\hline
\end{tabular}

Table 5. Association of response with PFS and OS in the maintenance arm.

\begin{tabular}{|c|c|c|c|c|c|c|c|c|}
\hline Character & $\begin{array}{l}\text { Mean } \\
\text { Estimate }\end{array}$ & $\begin{array}{l}95 \% \mathrm{Cl} \\
\text { Lower }\end{array}$ & Upper & $\begin{array}{c}\text { Median } \\
\text { Estimate } \\
\text { OS }\end{array}$ & $\begin{array}{l}95 \% \mathrm{Cl} \\
\text { Lower }\end{array}$ & Upper & Log rank & P value \\
\hline \multicolumn{9}{|l|}{$\begin{array}{l}\text { Initial response } \\
\text { to chemotherapy }\end{array}$} \\
\hline Responders (PR, CR) & 30.21 & 23.54 & 36.89 & - & - & - & 5.302 & 0.021 \\
\hline Non- responders (SD) & 19.07 & 15.88 & 22.26 & 17.00 & 13.13 & 20.87 & & \\
\hline \multicolumn{9}{|l|}{ Response after } \\
\hline Responders (CR, PR) & 31.3 & 27.85 & 34.82 & 34.00 & - & - & 5.615 & 0.018 \\
\hline \multirow[t]{2}{*}{ Non-responders (PD, SD) } & 18.32 & 14.69 & 21.94 & 17.00 & 13.80 & 20.22 & & \\
\hline & PFS & & & & & & & \\
\hline \multicolumn{9}{|l|}{$\begin{array}{l}\text { Initial response } \\
\text { to chemotherapy }\end{array}$} \\
\hline Responders & 19.8 & 14.30 & 25.42 & - & - & - & 1.7 & 0.18 \\
\hline Non-responders & 13.5 & 10.9 & 17.1 & 12.00 & 10.6 & 13.37 & & \\
\hline \multicolumn{9}{|l|}{$\begin{array}{l}\text { Response after } \\
3 \mathrm{~m} \text { of maintenance }\end{array}$} \\
\hline Responders (CR, PR) & 26.8 & 18.7 & 34.9 & - & - & - & 10.03 & 0.002 \\
\hline Non-responders (PD, SD) & 11.07 & 9.5 & 12.6 & 10.00 & 5.98 & 14.02 & & \\
\hline
\end{tabular}

Table 6. Toxicity analysis in both arms during the maintenance therapy.

\begin{tabular}{|c|c|c|c|c|}
\hline Toxicity & $\begin{array}{c}\text { Arm1 } \\
(n=46) \text { No. (\%) }\end{array}$ & $\begin{array}{c}\text { Arm2 } \\
(n=46) \text { No. (\%) }\end{array}$ & $x^{2}$ & $P$ value \\
\hline \multicolumn{5}{|l|}{ Anemia } \\
\hline $\mathrm{Gl}$ & $24(52.2)$ & $15(32.6)$ & & \\
\hline GII & $10(21.7)$ & $8(17.4)$ & 9.02 & 0.017 \\
\hline GIII & $2(4.3)$ & $0(0.0)$ & & \\
\hline No & $10(21.7)$ & $23(50)$ & & \\
\hline \multicolumn{5}{|c|}{ Neutropenia } \\
\hline GII & $2(4.3)$ & $0(0.0)$ & 2.04 & 0.49 \\
\hline No & $44(95.7)$ & $46(100)$ & & \\
\hline \multicolumn{5}{|c|}{ Thrombocytopenia } \\
\hline G1 & $2(4.3)$ & $0(0.0)$ & 2.04 & 0.49 \\
\hline No & $44(95.7)$ & $46(100)$ & & \\
\hline \multicolumn{5}{|c|}{ Vomiting grade } \\
\hline G1 & $2(4.3)$ & $6(13.0)$ & 1.23 & 0.26 \\
\hline No & $44(95.7)$ & $40(87)$ & & \\
\hline \multicolumn{5}{|c|}{ Diarrhea grade } \\
\hline G I & $2(4.3)$ & $0(0.0)$ & & \\
\hline G II & $4(8.7)$ & $0(0.0)$ & 10.25 & 0.001 \\
\hline G III & $4(8.7)$ & $0(0.0)$ & & \\
\hline No & $36(78.3)$ & $46(100)$ & & \\
\hline \multicolumn{5}{|c|}{ Neuropathy } \\
\hline G I & $26(56.5)$ & 41 (89.1) & & \\
\hline G II & $14(30.4)$ & $0(0.0)$ & 24.58 & $<0.001$ \\
\hline G III & $4(8.7)$ & $0(0.0)$ & & \\
\hline No & $2(4.3)$ & $5(10.9)$ & & \\
\hline \multicolumn{5}{|c|}{ Bone pain } \\
\hline G I & $2(4.3)$ & $4(8.7)$ & 2.28 & 0.437 \\
\hline G II & $2(4.3)$ & $0(0.0)$ & & \\
\hline No & 42 (91.3) & 42 (91.3) & & \\
\hline
\end{tabular}


Table 7. Quality of life (QOL) analysis in both arms.

\begin{tabular}{llcccc}
\hline character & QOLQ & $\begin{array}{c}\text { Arm (1) } \\
(\mathrm{n}=46) \text { Mean } \pm S D\end{array}$ & $\begin{array}{c}\text { Arm (2) } \\
(\mathrm{n}=46) \text { Mean } \pm S D\end{array}$ & U test & P value \\
\hline Global & Base line & $4.88 \pm 1.24$ & $4.45 \pm 1.44$ & 1.53 & 0.128 \\
health & Second & $4.97 \pm 1.26$ & $4.56 \pm 1.04$ & 1.77 & 0.076 \\
(C30) & P value & 0.73 & 0.598 & & \\
\hline Functional & Baseline & $1.97 \pm 0.54$ & $2.04 \pm 0.72$ & 0.53 & 0.599 \\
scale & Second & $1.76 \pm 0.55$ & $1.80 \pm 0.41$ & 1.66 & 0.095 \\
(C30) & P value & 0.067 & 0.338 & & \\
\hline Symptom & Base line & $1.56 \pm 0.54$ & $1.82 \pm 0.56$ & 1.41 & 0.16 \\
scale & Second & $1.76 \pm 0.55$ & $1.80 \pm 0.41$ & 0.57 & 0.56 \\
(C30) & P value & 0.032 & 0.223 & & \\
\hline LC 13 & LC1 & $1.69 \pm 0.36$ & $1.70 \pm 0.23$ & 0.51 & 0.61 \\
& LC2 & $1.66 \pm 0.38$ & $1.52 \pm 0.15$ & 2.15 & 0.031 \\
& P value & 0.433 & $<0.001$ & & \\
\hline
\end{tabular}

There was also no significant difference between the base line specific lung cancer module (LC13) in both arms ( $P$ value $=0.61)$. However, there was a statistically significant difference between the base line symptom scale (at the time of randomization) and after 3 months of maintenance therapy in maintenance arm. Patients after maintenance therapy showed better symptom scale than before maintenance therapy ( $P$ value $=0.032)$.

There was highly significant difference between the base line specific lung cancer module LC13 (LC1, at time of randomization) and the second one (LC2, after 3 months of follow up) in the observation arm. The patients showed better specific lung cancer module at the time of randomization than after following up ( $P$ value $=<0.001)$. similarly, there was statistically significant association between second lung cancer specific module LC13 (after 3 months of maintenance therapy and maintenance arm, patients received maintenance therapy showed better module when compared to observation arm ( $P$ value $=0.031)$. There was no statistically significant difference in the progression free survival (PFS) in both arms. The median PFS for maintenance arm was 10 months, while 8 months for observation arm ( $P$ value $=0.16$ ) (Figure 1). The median overall survival (OS) in the maintenance arm was 29 months, while it was 12.5 months for the observation arm with significant $P$ value of 0.047 (Figure 2).

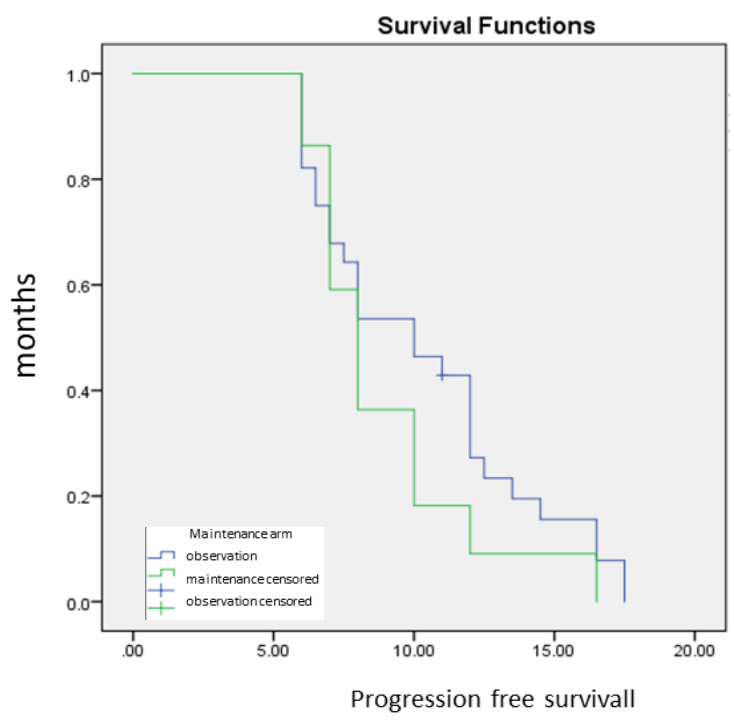

Figure 1. Progression free survival in both arms

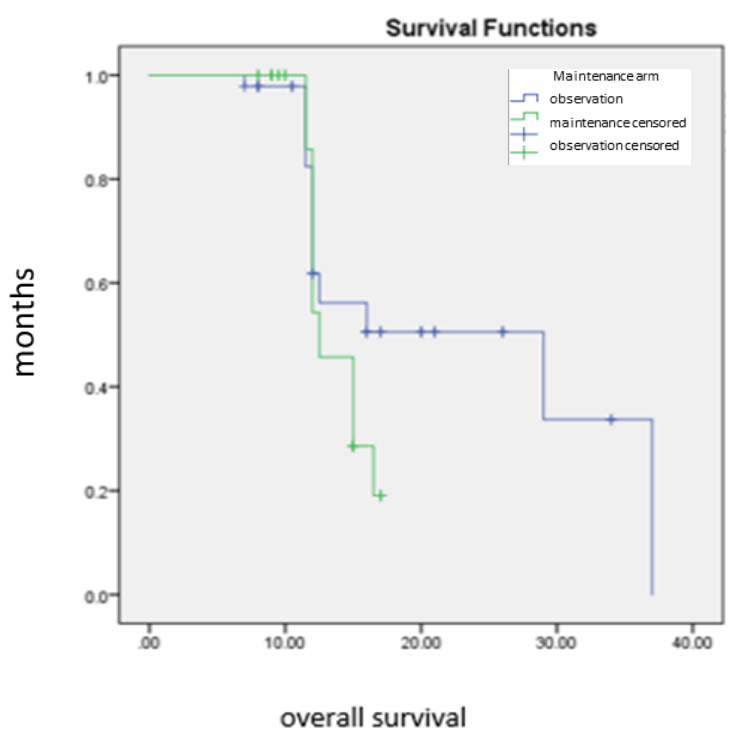

Figure 2. Overall survival (OS) in both arms 


\section{DISCUSSION}

The maintenance therapy is one strategy that has been evaluated extensively in recent years. It has been the focus of considerable debate and many questions remain regarding the optimal utilization of this strategy (Coate et al., 2009). It refers to systemic therapy that may be given to patients with advanced NSCLC after 4-6 cycles of first line chemotherapy. However, patients are only candidates for maintenance therapy if they have responded to previous treatment, or have stable disease, or they have not progressed (Gridelli et al., 2012). Maintenance therapy is not curative; its goal is to extend the survival and improve the quality of life during survival (Ahn et al., 2012). Till now, maintenance therapy is not considered as standard of care for all patients (e.g., not recommended for patients with PS 3-4, those with progression) (Hashemi-Sadraei and Pennell, 2012).

To our knowledge, there were only 2 studies that evaluated paclitaxel as a maintenance therapy. It is important to note that both studies were designed to compare the efficacy and safety of the different weekly paclitaxel regimens with carboplatin as first line therapy in advanced NSCLC and were not specifically designed to address the efficacy of continuation maintenance paclitaxel. In the study conducted by Belani et al, 401 patients were initially treated with one of three paclitaxel/carboplatin induction regimens for 16 weeks. Patients who responded ( $n=130$ ) were randomly assigned to either weekly paclitaxel therapy $(n=65)$ or observation ( $n=65$ ). (Belani et al.,2003). In the study by Belani et al., patients with previously untreated stage IIIB/IV NSCLC were randomly assigned to either arm 1 (carboplatin every 4 weeks with weekly paclitaxel) or arm 2 (carboplatin and paclitaxel, both administered every 3 weeks). Following 4 cycles of therapy, patients with response or SD were eligible to receive MT with weekly paclitaxel until progression (Belani et al., 2008).

The present prospective study evaluated the effect of weekly paclitaxel as a continuation maintenance therapy in advanced NSCLC patients after first line chemotherapy in patients with advanced NSCLC. Only 92 patients out of the enrolled 118 patients were able to complete the initial 4 cycles of chemotherapy; the other patients were excluded. We found that the most common cause of exclusion was either disease progression or toxicity namely neuropathy similar to those reported by Belani et al., 2003. In present study, eligible patients were randomized into 2 arms (after receiving 4 cycles of carboplatin paclitaxel doublets without disease progression and no significant toxicity). One arm of 46 patients received maintenance weekly paclitaxel (maintenance arm). The other arm with 46 patents received supportive treatment only and kept under follow up.

Comparison between both arms as regard demographics, response, toxicity during the maintenance period, quality of life before and after maintenance therapy, progression free survival (PFS), and overall survival (OS) were conducted. By comparing both arms regarding patients' demographics at presentation there was no significance difference regarding age, gender, performance status, tumor pathology and stage indicating homogeneity of both groups. At the time of randomization, there was no significant difference between both arms regarding response to initial platinum doublets. After 3 months of maintenance therapy, there was significant difference between both groups regarding response in favor of maintenance arm compared to observation arm.

As regard to the progression free survival (PFS), paclitaxel therapy delayed the time to disease progression (the median PFS was 10 months in the maintenance arm versus 8 months in the observation arm), which is comparable to the results of Belani et al., (Belani et al., 2003) who found that the time to disease progression in paclitaxel maintenance arm was 38 weeks versus 29 weeks in the observation arm. Similar results were also reported by Belani and his colleagues in another study (Belani et al.,2008). These results were globally consistent with other studies by Paz-Ares et al., Ciuleanu et al., and Barlesi et al who evaluated MT with other chemotherapeutic and biological agents. Their studies indicated that maintenance therapy can delay the time to progression in patients eligible to receive this treatment. (Paz-Ares et al., 2012, Ciuleanu et al., 2009, Barlesi et al., 2013). 
As regard to the overall survival (OS), median OS in the maintenance arm was longer than that is the observation arm (29 versus 12.5 months). Belani et al., however, showed survival benefit with the maintenance paclitaxel but it did not reach statistically significant difference; 75 weeks for maintenance arm versus 60 weeks for observation arm (Belani et al.,2003). In study by Belani et al, they found significant difference in Median, it was 76 weeks (MT) versus 29 weeks (no MT) (Belani et al., 2008). The overall survival advantage in maintenance therapy arm can be explained by its ability to improve the general condition of the patients and maintained their good performance status and survived longer so be able to continue second and even third lines chemotherapy.

Further analysis of patients in the maintenance arm alone revealed that initial response to the first line chemotherapy affected the overall survival, responders (CR. PR) who showed longer OS than non-responders (SD); the median OS for responders was not reached versus 17 months for non-responders. These results are in line with those of Perol et al., who investigated whether the continuation maintenance with gemcitabine or switch maintenance with erlotinib and found that the magnitude of response to induction chemotherapy affected OS benefit for continuation maintenance. (Pérol et al., 2012). We found that maintained response after 3 months of chemotherapy also associates with prolonged PFS and OS. The median duration of paclitaxel therapy was 6 cycles ( 18 weeks) and only 14 patients continued maintenance paclitaxel till end of the current study. Most patients who completed paclitaxel maintenance therapy till the end of follow up period were: PS 0 , stage IIIB, grade II tumors, and all of them was adenocarcinoma histology. There was highly significant association between duration of paclitaxel therapy and PFS. Based on these findings the authors recommend maintenance therapy to group of patients with features.

Treatment related toxicities namely anemia, diarrhea and peripheral neuropathy were significantly higher in the maintenance arm compared to observation arm. Grade III toxicities namely anemia, neuropathy and diarrhea were reported in $(4.3 \%, 8.7 \%$ and $8.7 \%)$ of maintenance arm patients respectively. Belani et al., found that $86 \%$ of patients in the treatment group experienced one adverse event, and $45 \%$ experienced at least one grade 3 or 4 adverse event (Belani et al., 2003). There was no significant difference between global health status, functional, symptom scales at the time of randomization and after 3 months of maintenance therapy in both arms. While in the maintenance arm in contrast to observation arm, the patients showed better symptom scale after 3 months of maintenance than before and there was statistically significant association between second lung cancer specific module LC13 after 3 months of maintenance therapy. Other studies on other chemotherapeutic agents Brodowicz et al., and Zhang et al., showed better lung cancer symptom scale (LCSS) in the maintenance arms. (Brodowicz et al., 2005, Zhang et al., 2012).

In conclusion, our study indicates that the maintenance treatment with paclitaxel in patients with advanced NSCLC associates with better overall survival advantage than in the observation arm. Although toxicity was higher in the maintenance arm, the QOL was not significantly affected with better symptom scale in maintenance group. As targeted therapy is not available for many patients in less developed countries, The authors suggest maintenance paclitaxel as a reasonable treatment option in patients with NSCLC particularly those with performance status 0 , adenocarcinoma histology, less advanced stage, grade II tumors who experienced complete or partial response after initial carboplatin paclitaxel treatment.

\section{Acknowledgement}

The authors thank all participant for their participation and cooperation.

\section{Conflict of interest}

Authors declare that they have no conflicts of interest.

\section{References}

Planchard D, Popat S, Kerr K, Novello S, Smit EF, Faivre-Finn C, et al. Metastatic non-small cell lung cancer: ESMO Clinical Practice Guidelines for diagnosis, treatment and follow-up. Annals of Oncology. 2019 May 1;30(5):86370. 
Barlesi F, Park K, Ciardiello F, Pawel JV, Gadgeel S, Hida $\mathrm{T}$, et al. Primary analysis from OAK, a randomized phase III study comparing atezolizumab with docetaxel in $2 \mathrm{~L} / 3 \mathrm{~L}$ NSCLC(abstract).Presented at the 2016 Annual Meeting European Society for Clinical Oncology (ESMO).

Rossi A, Chiodini P, Sun JM, O'Brien ME, von Plessen C, Barata $\mathrm{F}$, et al. Six versus fewer planned cycles of first-line platinum-based chemotherapy for non-small-cell lung cancer: a systematic review and meta-analysis of individual patient data. The Lancet Oncology. 2014 Oct 1;15(11):1254-62.

Coate LE, John T, Tsao MS, Shepherd FA. Molecular predictive and prognostic markers in nonsmall-cell lung cancer. The lancet oncology. 2009 Oct 1;10(10):1001-10.

Custodio A, de Castro J. Strategies for maintenance therapy in advanced non-small cell lung cancer: current status, unanswered questions and future directions. Critical reviews in oncology/hematology. 2012 Jun 1;82(3):33860.

Eisenhauer EA, Therasse $P$, Bogaerts J, Schwartz LH, Sargent D, Ford R, et al. New response evaluation criteria in solid tumours: revised RECIST guideline (version 1.1). Eur J Cancer. 2009 Jan; 45(2):228-47.

Gridelli C, de Marinis F, Di maio M, Ardizzoni A, Chandra P. Belani, et al. Maintenance treatment of advanced non-small cell lung cancer: results of an international expert panel meeting of the Italian association of thoracic oncology. Lung Cancer 2012; 76:269279.

Ahn M J, Sun JM, Ahn JS, Park K. The effectiveness of maintenance pharmacotherapies for nonsmall cell lung cancer. Clinical Medical Insights. Oncology 2012.6:253-262.

Hashemi-Sadraei N, Pennell NA. Advanced non-small cell lung cancer (NSCLC): maintenance therapy for all? Current treatment options in oncology. 2012 Dec 1;13(4):478-90.

Belani CP, Barstis J, Perry MC, La Rocca RV, Nattam $S R$, Rinaldi D, et al. Multicenter, Randomized Trial for Stage IIIB or IV Non-Small-Cell Lung Cancer Using Weekly Paclitaxel and Carboplatin Followed by Maintenance Weekly Paclitaxel or Observation.J Clin Oncol 2003; 21:2933-2939.

Belani CP, Ramalingam S, Perry MC, LaRocca RV, Rinaldi D, Gable PS, et al. Randomized, phase III study of weekly paclitaxel in combination with carboplatin versus standard every-3weeks administration of carboplatin and paclitaxel for patients with previously untreated advanced non-small-cell lung cancer. Journal of Clinical Oncology. 2008 Jan 20;26(3):468-73.

Paz-Ares L, de Marinis F, Dediu M, Thomas M, Pujol $\mathrm{JL}$, Bidoli $\mathrm{P}$, et al. Maintenance therapy with pemetrexed plus best supportive care versus placebo plus best supportive care after induction therapy with pemetrexed plus cisplatin for advanced non-squamous nonsmall-cell lung cancer (PARAMOUNT): a double-blind, phase 3, randomised controlled trial. Lancet Oncol. 2012; 13:247-255.

Ciuleanu T, Brodowicz T, Zielinski C, Kim JH, Krzakowski M, Laack E, et al. Maintenance pemetrexed plus best supportive care versus placebo plus best supportive care for nonsmall-cell lung cancer: a randomised, doubleblind, phase 3 study Lancet. 2009; 374:14321440

Barlesi F, Scherpereel A, Rittmeyer A, Pazzola A, Tur $\mathrm{NF}, \mathrm{Kim} \mathrm{JH}$, et al. Randomized phase III trial of maintenance bevacizumab with or without pemetrexed after first- line induction with bevacizumab, cisplatin, and pemetrexed in advanced nonsquamous non-small-cell lung cancer: AVAPERL (MO22089). J Clin Oncol 2013; 31:3004-3011.

Pérol M, Chouaid C, Pérol D, Barlési F, Gervais R, Westeel V, et al. Randomized, phase III study of gemcitabine or erlotinib maintenance therapy versus observation, with predefined second-line treatment, after cisplatingemcitabine induction chemotherapy in advanced non-small-cell lung cancer. Journal of Clinical Oncology. 2012 Oct 1;30(28):351624.

Brodowicz T, Krzakowski M, Zwitter M, Tzekova V, Ramlau R, Chilezan N, et al. Cisplatin and gemcitabine first-line chemotherapy followed by maintenance gemcitabine or best supportive care in advanced non-small cell lung cancer: a phase III trial. Lung Cancer 2006; 52:155-163.

Zhang L, Ma S, Song X, Han B, Cheng Y, Huang C, et al. Gefitinib versus placebo as maintenance therapy in patients with locally advanced or metastatic non-small-cell lung cancer (INFORM; C-TONG 0804): a multicentre, double-blind randomised phase 3 trial. Lancet Oncol. 2012. 



\section{Egyptian Association for Cancer Research (EACR)}

http://eacr.tanta.edu.eg/

EACR is an NGO society that was declared by the Ministry of Social Solidarity (Egypt) No. 1938 in 19/11/2014 based on the initiative of Prof. Mohamed Labib Salem, the current Chairman of EACR. EACR aims primarily to assist researchers, in particular young researchers in the field of cancer research through workshops, seminars and conferences. Its first international annual conference entitled "Anti-Cancer Drug Discovery" was successfully organized in April 2019 (http://acdd.tanta.edu.eg). Additionally, EACR aims to raise the awareness of the society about the importance of scientific research in the field of cancer research in prediction, early diagnosis and treatment of cancer. EACR is also keen to outreach the scientific community with periodicals and news on cancer research including peer-reviewed scientific journals for the publication of cutting-edge research. The official scientific journal of EACR is "International Journal of Cancer and biomedical Research (IJCBR: https://jcbr.journals.ekb.eg) was successfully issued in 2017 and has been sponsored by the Egyptian Knowledge Bank (EKB: www.ekb.eg).

\section{EACR Chairman,}

Prof. Mohamed Labib Salem, PhD

Professor of Immunology

Faculty of Science, Tanta Universiy, Egypt 


\section{Editor-in-Chief}

Mohamed Labib Salem, PhD

Tanta University, Egypt

\section{Managing Editor}

Nehal Elmashad, MD

Tanta University, Egypt

Nabil Mohy Eldin, PhD

Kafrelsheikh University, Egypt

Doaa Al-Ghareeb, PhD

Alexandria University, Egypt

Abdel-Aziz Zidan, PhD

Damanhour University, Egypt

Wesam Meshrif, PhD

Tanta University, Egypt

Rasha Eraky, MD

Tanta University, Egypt

\section{Associate Editor}

Hesham Tawfik

Tanta University, Egypt

Mostafa El-Sheekh

Tanta University, Egypt

Yousry Albolkiny, PhD

Tanta University, Egypt

Gamal Badr

Assuit University, Egypt

Elsayed Salim

Tanta University, Egypt

Essam Elshiekh

Tanta Cancer Center, Egypt

\section{Editorial Board}

\author{
Alberto Montero \\ Taussig Cancer Center, \\ Cleveland, USA \\ Marcela Diaz \\ Cleveland Clinic Foundation, USA \\ Yi Zhang \\ Zhengzhou University, China \\ Shengdian Wang \\ Chinese Academy of Sciences, \\ China \\ Faris Alenzi \\ Prince Sattam bin Abdulaziz \\ University, KSA \\ Mark Robunstein \\ Medical University of South \\ Carolina, USA \\ Mamdooh Ghoneum, DSc \\ Charles Drew University of \\ Medicine \& Science, USA
}

Natarajan Muthusamy, DVM

The Ohio State University, USA

Hideki Kasuya MD, PhD,

FACS

Nagoya University, Japan

Sherif El-Khamisy, MD

Sheffield University, UK

Mohamed Abou-El-Enein,

MD

Charité Universitätsmedizin

Berlin, Germany

Alaa Eldin Almostafa, MD

McGill University, Canada

Amr Amin

United Arab Emirates

University, UAE

AbdeIRahman Zekri

National Cancer Institute, Egypt

Mohamed Attia, MD

Tanta University, Egypt

Mohamed Elshanshory, MD

Tanta University, Egypt

Hussein Khamis

Alexandria University, Egypt

Magdy Mahfouz

Kafr Elsheikh University, Egypt

Ehab Elbedewey

Tanta University, Egypt

Abeer Badr

Cairo University, Egypt

Nadia Hamdy, PharmD

Ain Shams University, Egypt

Ibrahim El-Sayed

Menoufia University, Egypt

Tarek Aboul-Fadl, PharmD

Assiut University, Egypt

Mohamed Noureldin

Banaha University, Egypt

Haiam Abou Elela

National Institute of

Oceanography and Fisherie,

Egypt

Sameh Ali, MD

Nationa Liver Institute, Egypt

Maha EL-Demellawi

City for Scientific Research \&

Technology Applications, Egypt

Desouky A Abd-El-Haleem

City for Scientific Research \&

Technology Applications, Egypt
Ashraf Tabll

National Research Center, Egypt

Wael Lotfy, MD

Alexandria University, Egypt

Olfat Gadallah, MD

Tanta University, Egypt

Nahla Shoukry

Suez University, Egypt

Medhat Eldenary

Tanta University, Egypt

Nagla Sarhan, MD

Tanta University, Egypt

Naglaa Fathy, MD

Zagazik University, Egypt

Azza Hasan Mohamed Menufia University, Egypt

Nanees Gamal Eldin

Tanta University, Egypt

Mohamed Mansour, UK

Sabbah Hammoury

Alexandria Ayadi Almostaqbal

Oncology Hospital, Egypt

Nehal Aboulfotoh

Zewail City for Science and

Technology, Cairo, Egypt

Amir Elkhami

Galaxo, San Francisco, USA

Rabab Khairat

National Research Center,

Giza, Egypt

Ahmed Alzohairy

Zagazi University, Egypt

Wgady Khalil

National Research Center, Egypt

Sayed Bakry

Alazhar University, Egypt

Mohamed Ghanem, MD

Kafr Elshikh University, Egypt

Mohamed Salama, MD

Mansoura University, Egypt

Mona Marie, MD

Alexandria University, Egypt

\section{For more information, contact}

Hamdi Kandil

Tanta University, Egypt

Email: ljcbr100@gmail.com 